\title{
AL-QARDH AL-HASAN: SOFT AND BENEVOLENT LOAN PADA BANK ISLAM
}

\author{
Ismail Hannanong \\ Sekolah Tinggi Agama Islam (STAI) Al Gazali Barru \\ ismailhananonggmail.com \\ Aris \\ Institut Agama Islam Negeri (IAIN) Parepare \\ Arisrauf31 gmail.com
}

\begin{abstract}
Akad Al-Qardh is an agreement or agreement between the two parties, whereby the first party provides assets or provides property in the sense of lending to a second party as a borrower of money or a person who receives assets that can be billed or reimbursed, in other words lend property to other people who need fast funds without expecting rewards. For its practice in the Islamic banking of Al Qardh Al Hasan serves as a bailout fund for a short period of time, the customer will return it quickly, as a facility to obtain funds quickly because the customer cannot withdraw the funds, for example due to being stranded in deposits, as a facility to help small and medium businesses or social community. The benefits of aqad alqardh are helping customers who need fast funds, as well as one of the giver characteristics between Islamic banks and conventional banks which contain social missions, in addition to commercial missions, improve good image and increase community loyalty to Islamic banks.
\end{abstract}

Keyword: al-Qardh, Islamic Bank, Agreement

Abstrak : Akad Al-Qardh adalah perikatan atau perjanjian antara kedua belah pihak, dimana pihak pertama menyediakan harta atau memberikan harta dalam arti meminjamkan kepada pihak kedua sebagai peminjam uang atau orang yang menerima harta yang dapat ditagih atau diminta kembali harta tersebut, dengan kata lain meminjamkan harta kepada orang lain yang mebutuhkan dana cepat tanpa mengharapkan imbalan. Untuk Praktiknya dalam perbankan syariah Al Qardh Al Hasan berfungsi sebagai dana talangan untuk jangka waktu singkat, maka nasabah akan mengembalikannya dengan cepat, sebagai fasilitas untuk memperoleh dana cepat karena nasabah tidak bisa menarik dananya, misalnya karena tersimpat dalam deposito, sebagai fasilitas membantu usaha kecil menengah atau sosial kemasyarakatan. Manfaat aqad al-qardh adalah membantu nasabah yang membutuhkan dana cepat, sekaligus salah satu ciri pemberi antara bank syariah dan bank konvensional yang di dalamnya terkandung misi sosial, disamping misi komersial, meningkatkan citra baik dan meningkatkan loyalitas masyarakat terhadap bank syariah.

Kata Kunci : Al-Qardh, Perjanjian, Bank Syariah 

171 | Diktum: Jurnal Syari'ah dan Hukum, Volume 16, Nomor 2 Desember 2018 : 171 - 182

\section{PENDAHULUAN}

Islam mengakui adanya perbedaan pendapatan dan kekayaan pada setiap orang dengan syarat bahwa perbedaan tersebut diakibatkan karena setiap orang mempunyai perbedaan keterampilan, inisiatif, usaha dan resiko. Namun perbedaan itu tidak boleh menimbulkan kesenjangan yang terlalu jauh antara yang kaya dengan yang miskin karena kesenjangan yang terlalu dalam tidak sesuai dengan syariah Islam yang menekankan bahwa sumber-sumber daya bukan saja karunia dari Allah bagi semua manusia, melainkan juga merupakan suatu amanah.

Oleh karena itu tidak ada alasan untuk mengkonsentrasikan sumber-sumber daya di tangan segelintir orang.

Kurangnya program-program efektif untuk mereduksi kesenjangan sosial yang terjadi selama ini dapat mengakibatkan kehancuran, bukan penguatan perasaan persaudaraan yang hendak diciptakan ajaran Islam. Syariah Islam sangat menekankan adanya suatu distribusi kekayaan dan pendapatan yang merata sebagaimana yang tercantum dalam QS. Al Hasyr/59: 7,

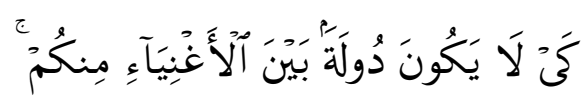

Terjemahnya:

“...kekayaan itu tidak beredar di kalangan orang-orang kaya di antara kamu saja."

Distribusi kekayaan dan pendapatan yang merata bukan berarti sama rata sebagaimana faham kaum komunisme, tetapi ajaran Islam mewajibkan setiap individu untuk berusaha memenuhi kebutuhan hidupnya, dan sangat melarang seseorang menjadi pengemis untuk menghidupi dirinya.

Dalam literatur Ekonomi Syariah, terdapat berbagai macam bentuk transaksi kerjasama usaha, baik yang bersifat komersial maupun sosial, salah satu berbentuk "Al-Qardh". AlQardh adalah pemberian harta kepada orang lain yang dapat ditagih atau diminta kembali tanpa mengharapkan imbalan atau dengan kata lain 
172 | Diktum: Jurnal Syari'ah dan Hukum, Volume 16, Nomor 2 Desember 2018 : 171 - 186

merupakan sebuah transaksi pinjam meminjam tanpa syarat tambahan pad asaat pengembalian pinjaman. Dalam literatur fiqh klasik, qardh dikategorikan dalam aqd tathawwui atau akad tolong menolong dan bukan transaksi komersial.

Al-Qardh adalah dana talangan atau pinjaman bagi orang yang membutuhkan dana cepat, dan alqardh ini merupakan salah satu jasa bank dalam melayani masyarakat, selain kafalah, hiwalah dan lain-lain. Dalam melakukan akad al-qardh ini tentunya ada rukun, syarat, dan macam-macam perjanjian atau perikatan. Dalam peraktinya al-qard ini bebeda dengan praktik akad-akad yang lainnya, karena dalam al-qardh ini termasuk akad tabarru atau akad tolong menolong dalam arti akad ini tidak mengambil keuntungan. Tulisan ini akan mengukapkan penjelasan tentang praktik perikatan dalam aqad qardh atau dana talangan dalam dunia perbankan Islam.

\section{PEMBAHASAN}

\section{A. Pengertian Aqad al Qard}

Istilah "perjanjian" dalam hukum Indonesia disebut "Akad" dalam hukum Islam. Kata akad berasal dari kata "al-'Aqdu", yang berarti mengikat, menyambung atau menghubungkan $(a l-r a b t){ }^{1} \quad$ Menurut bahasa 'Aqad mempunyai beberapa arti, antara lain:

1. Mengikat (al-Rabthu), yaitu "Mengumpulkan dua ujung tali dan mengikat salah satunya dengan yang lain sehingga bersambung, kemudian keduanya menjadi sebagai sepotong benda."

2. Sambungan ('Aqdah), yaitu "Sambungan yang memegang kedua ujung itu dan mengikatkatnya."

3. Janji (al-'Ahd), yaitu dijelaskan dalam QS. Al Imran/3: 76

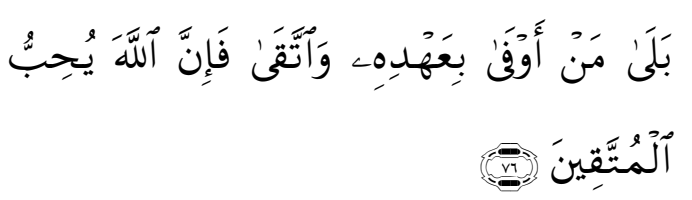

Terjemahnya:

Siapa yang menepati janji (yang dibuat)nya dan bertakwa, Maka Sesungguhnya Allah menyukai orang-orang yang bertakwa. 


\author{
Dari uraian diatas dapat \\ dipahami bahwa setiap akad \\ (persetujuan) mencakup tiga hal, \\ yaitu: \\ 1. Perjanjian (' $a h d u)$; \\ 2. Persetujuan dua buah perjanjian \\ atau lebih;
}

3. Perikatan ('aqdu). ${ }^{2}$

Sebagai suatu istilah hukum Islam, ada beberapa definisi yang diberikan kepada aqad atau perjanjian. Menurut Pasal 262 Mursyid al-Haira, akad merupakan pertemuan ijab yang diajukan oleh salah satu pihak dengan kabul dari pihak lain yang menimbulkan akibat hukum pada objek akad. ${ }^{3}$ Menurut penulis, akad adalah pertemuan ijab dan kabul sebagai pernyataan kehendak dua pihak atau lebih untuk melahirkan suatu akibat hukum pada objeknya.

Dari kedua definisi diatas memperlihatkan bahwa: Pertama, akad merupakan keterkaitan atau pertemuan ijab dan kabul yang berakibat timbulnya akad hukum. Ijab adalah penawaran yang diajukan oleh salah satu pihak, dan kabul adalah jawaban persetujuan yang diberikan mitra akad sebagai tanggapan terhaadap penawaran pihak yang pertama. Akad tidak terjadi apabila pernyataan kehendak masing-masing pihak tidak terkait satu sama lain karena akad adalah keterkaitan kehendak kedua belah pihak yang tercermin dalam ijab dan kabul.

Kedua, akad merupakan tindakan hukum dua pihak karna akad adalah ijab yang merepresentasikan kehendak dari satu pihak dan kabul yang menyatakan kehendak pihak lain. Ketiga, tujuan akad adalah untuk melahirkan suatu akibat hukum. Lebih tegas lagi tujuan akad adalah maksud bersama yang dituju dan yang hendak diwujudkan oleh para pihak melalui pembuatan akad. Akibat hukum akad dalam hukum Islam disebut "Hukum Akad" (hukum al-'Aqdi). ${ }^{4}$

Pengertian akad dalam terminologi lainya adalah sebagai berikut :

1. Perikatan ijab dan qabul yang dibenarkan syara' yang 
174 | Diktum: Jurnal Syari'ah dan Hukum, Volume 16, Nomor 2 Desember 2018 : 171 - 186

menetapkan keridhaan kedua

belah pihak.

2. Berkumpulnya serah terima diantara dua pihak atau perkataan seseorang yang berpengaruh pada kedua pihak.

3. Terkumpulnya persyaratan serah terima atau sesuatu yang menunjukkan adanya serah terima yang disertai dengan kekuatan hukum."

4. Ikatan atas bagian-bagian tasharruf menurutnya syara' dengan cara serah terima. ${ }^{5}$

Al-Qardh adalah pemberian harta kepada orang lain yang dapat ditagih atau diminta kembali atau dengan kata lain meminjamkan tanpa mengharapkan imbalan. Dalam literatur fiqh klasik, qardh dikategorikan dalam aqad tathawwui atau akad saling membantu dan bukan transaksi komersial. ${ }^{6}$ Secara syar'i para ahli fiqh mendefinisikan Qardh :

1. Menurut Madzhab Hanafi, Ibn Abidin mengatakan bahwa suatu pinjaman adalah apa yang dimiliki satu orang lalu diberikan kepada yang lain kemudian dikembalikan dalam kepunyaannya dalam baik hati.

2. Menurut Madzhab Maliki mengatakan Qardh adalah Pembayaran dari sesuatu yang berharga untuk pembayaran kembali tidak berbeda atau setimpal.

3. Menurut Madzhab Hanbali Qardh adalah pembayaran uang ke seseorang siapa yang akan memperoleh manfaat dengan itu dan kembalian sesuai dengan padanannya.

4. Menurut Madzhab Syafi'i Qardh adalah Memindahkan kepemilikan sesuatu kepada seseorang, disajikan ia perlu membayar kembali kepadanya.

Dari berbagai pengertian akad dan al-Qardh diatas dapat disimpulkan bahwa akad $A 1-Q a r d h$ adalah perikatan atau perjanjian antara kedua belah pihak, dimana pihak pertama menyediakan harta atau memberikan harta dalam arti meminjamkan kepada pihak kedua sebagai peminjam uang 
atau orang yang menerima harta yang dapat ditagih atau diminta kembali harta tersebut, dengan kata lain meminjamkan harta kepada orang lain yang mebutuhkan dana cepat tanpa mengharapkan imbalan. Dalam akad al-Qardh ini, untuk menghindarkan diri dari riba, biaya administrasi pada pinjaman al-Qardh harus dinyatakan dalam nominal bukan presentase; Sifatnya harus nyata, jelas dan pasti serta terbatas pada hal-hal yang mutlak diperlukan untuk tejadinya kontrak; uang yang dijadikan sebagai biaya administrasi harus habis dalam waktu perikatan tersebut.

\section{B. Unsur-unsur dan Dasar Akad Al- Qardh}

Unsur-unsur dalam akad alQardh yaitu sebagai berikut: pertama, Pertalian Ijab dan Qabul; Ijab adalah pernyataan kehendak oleh suatu pihak (mujīb) untuk melakukan sesuatu atau tidak melakukan sesuatu. Qabul adalah pernyataan menerima atau menyetujui kehendak mukib tersebut oleh pihak lainnya (qabul). Ijab dan kabul harus ada dalam akad al-Qardh.

Kedua, dibenarkan oleh Syara'; Akad yang dilakukan tidak boleh bertentangan dengan syariah atau halhal yang diatur oleh Allah SWT dalam Al-Quran dan Nabi Muhammad SAW dalam Hadits. Pelaksanaan akd, tujuan akad, maupun objek akad tidah boleh bertentangan dengan syariah. Jika bertentsngan, akan mengakibatkan akad itu tidak sah. Ketiga, Mempunyai Akibat Hukum; Akad merupakan salah satu dari tindakan hukum(thassaruf). Adanya akad akan menimbulkan akibat hukum terhadap objek hukum yang diperjanjikan oleh para pihak dan juga memberikan konsekunesi hak dan kewajiban yang mengikat para pihak. ${ }^{7}$

\section{Landasan Hukumnya :}

1. Al-Quran

a. QS. Al-Hadid/57: 11

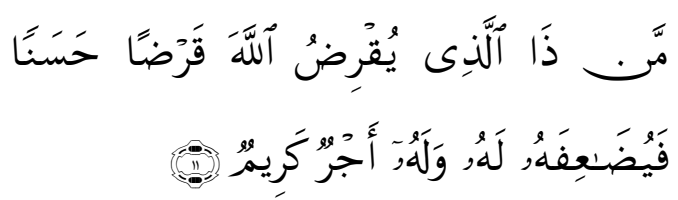

Terjemahnya:

Siapakah yang mau meminjamkan kepada Allah pinjaman yang baik, Maka Allah akan melipat- 
176 | Diktum: Jurnal Syari'ah dan Hukum, Volume 16, Nomor 2 Desember 2018 : 171 - 186

gandakan (balasan) pinjaman itu untuknya, dan Dia akan memperoleh pahala yang banyak.

Landasan dalil dalam ayat ini adalah manusia diseru untuk “meminjamkan kepada Allah", artinya untuk membelanjakan harta di jalan Allah. Selaras dengan meminjamkan kepada Allah, manusia juga diseru unutk "meminjamkan kepada sesama manusia", sebagai bagian dari kehidupan bermasyarakat (civil society).

b. QS Al : Baqarah/2: 245

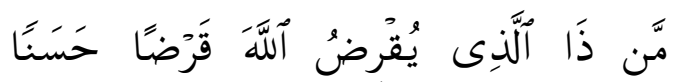

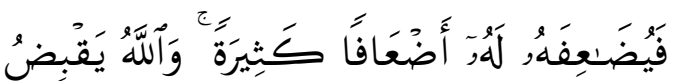

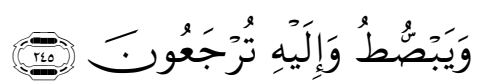

Terjemahnya:

Al-Qur'an Siapakah yang mau memberi pinjaman kepada Allah, pinjaman yang baik (menafkahkan hartanya di jalan Allah), maka Allah akan meperlipat gandakan pembayaran kepadanya dengan lipat ganda yang banyak. Dan Allah menyempitkan dan melapangkan (rezki) dan kepadaNya-lah kamu dikembalikan.

c. QS. Al-Māidah/5: 2

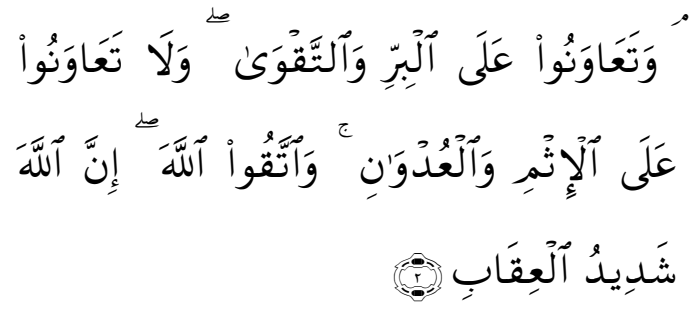

Terjemahnya:

Dan tolong-menolonglah kamu dalam (mengerjakan) kebajikan dan takwa, dan jangan tolongmenolong dalam berbuat dosa dan pelanggaran. Dan bertakwalah kamu kepada Allah, sesungguhnya Allah amat berat siksa-Nya.

2. Al-Hadits

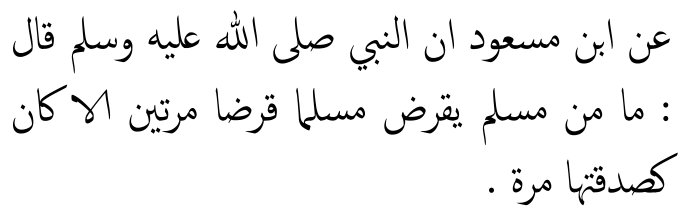

Artinya:

Ibnu Mas'ud meriwayatkan bahwa Nabi saw, berkata, "Bukan seorang muslim (mereka) yang meminjamkan muslim (lainnya) dua kali kecuali yang satunya adalah (senilai) sedekah". (HR: Ibnu Majah no. 2421, kitab alAhkam; Ibnu Hibban dan Baihaqi).

عن أنس بن مالك قال : قال رسول الله صلى الله عليه وسلم : رايت ليلة اسري بي علي باب الجنة مكتوبا الصدقة بعشر امثالها والقرض بثمنية عشر, 
فقلت يا جبريل ! ما بال القرض افضل من

الصدقة, قال : لا بال القرض افضل من الصدقة,

قال : لان السائل يسئل وعنده والمستقرض لا

يستقرض الا من حاجة .

Artinya:

"As-Sunnah Dari Anas ra, dia berkata, Rasulullah SAW bersabda : "Pada malam peristiwa Isra' aku melihat di pintu surga tertulis 'shadaqoh (akan diganti) dengan 10 kali lipat, sedangkan Qardh dengan 18 kali lipat, aku berkata : "Wahai jibril, mengapa Qardh lebih utama dari shadaqoh?' ia menjawab 'karena ketika meminta, peminta tersebut memiliki sesuatu, sementara ketika berutang, orang tersebut tidak berutang kecuali karena kebutuhan". (HR. Ibnu Majah dan Baihaqi dari Abas bin Malik ra, Thabrani dan Baihaqi meriwayatkan hadits serupa dari Abu Umamah ra) Ibnu Mas'ud meriwayatkan bahwa Nabi saw berkata,"Bukan seorang muslim (mereka) yang meminjamkan muslim (lainya) dua kali lipat kecuali yang satunya adalah (senilai) sedekah." (HR Ibnu Majah,Ibnu Hibban dan Baihaqi).

\section{Ijma}

Para ulama telah menyepakati bahwa al-qardh boleh dilakukan.
Kesepakatan ulama ini didasari tabiat manusia yang tidak bisa hidup tanpa pertolongan dan bantuan saudaranya. Tidak ada seorangpun yang memiliki segala barang yang ia butuhkaan. Oleh karena itu, pinjam-meminjam sudah menjadi satu bagian dari kehidupan $d u$ dunia ini. Islam adalah agama yang sangat memperhatikan segenap kebutuhan umatnya." 8

4. Fatwa DSN tentang Al-Qardh No :19/DSN-MUI/IV/2001

Fatwa Dewan Syariah Nasional menyebutkan:

Pertama : Ketentuan Umum Al-Qardh yang diberikan kepada nasabah (muqtaridh) yang memerlukan.

1. Al-Qardh adalah pinjaman yang diberikan kepada nasabah (muqtaridh) yang memerlukan

2. Nasabah al-Qardh wajib mengembalikan jumlah pokok yang diterima pada waktu yangtelah disepakati bersama.

3. Biaya administrasi dibebankan kepada nasabah. 
178 | Diktum: Jurnal Syari'ah dan Hukum, Volume 16, Nomor 2 Desember 2018 : 171 - 186

4. LKS dapat meminta jaminan kepada nasabah bilamana di pandang perlu.

5. Nasabh al-Qardh dapat memberikan tambahan (sumbangan) dengan sukarela kepada LKS selama tidak diperjanjikan dalam akad.

6. Jika nasabah tidak dapt mengembalikan sebagian atau seluruh kewajibannya pada saat yang telah disepakati dan LKS telah memastikan ketidakmampuannya, LKS dapat :

a. Memperpanjang jangka waktu pengambilan, atau

b. Menghapus (write off) sebagian atau seluruh kewajibannya.

Kedua : Sanksi

1. Dalam hal nasabah tidak menunjukan keinginan mengembalikan sebagian atau seluruh kewajibannya dan bukankarena ketidakmampuannya, LKS dapat menjatuhkan sanksi kepada nasabah.

2. Sanksi yang dijatuhkan kepada nasabah sebagaimana dimaksud butir 1 dapat berupa dan tidak terbatas pada penjualan barang jaminan.

3. Jika barang jaminan tidak mencukupi, nasabah tetap harus memenuhi kewajibannya secara penuh.

Ketiga : Sumber Dana

Dana al-Qardh dapat bersumber dari :

a. Bagian modal LKS;

b. Keuntungan LKS yang disisihkan; dan

c. Lembaga lain atau individu yang mempercayakan penyaluran infaqnya kepada LKS.

Keempat :

1. Jika salah satu pihak tidak memnunaikan kewajibannya atau jika terjadi perselisihan di antarapihak, maka penyelesainnya dilakukan melalui Badan Arbitrasi Syari'ah setelah tidak tercapai kesepakatan melalui musyawarah.

2. Fatwa ini berlaku sejak tanggal ditetapkan dengan ketentuan 
jika kemudian hari ternyata dapat kekeliruan, akan diubah disempurnakan sebagaimana mestinya.

\section{Rukun dan Syarat Al-Qardh}

Rukun dan syarat al qard adalah sebagai berikut:

1. 'Aqid ialah orang yang berakad (dua belah pihak), dalam arti pihak pertama adalah orang yang menyediakan harta atau pemberi harta (yang meminjamkan), dengan pihak kedua adalah orang yang membutuhkan harta atau orang yang menerima harta (meminjam). Seseorang yang berakad terkadang terkadang orang yang memiliki hak ('aqid ashli) dan merupakan wakil dari yang memiliki hak. ${ }^{9}$ Syarat dari kedua orang yang melakukan akad yaitu cakap bertindak (ahli), tidak sah akad orang yang tidak cakap bertindak, seperti orang gila, orang yang dibawah pengampuan (mahjur) karna boros atau lainnya.

2. Ma'qud 'alaih adalah benda-benda yang diakadkan, seperti benda (harta). Dalam arti setiap peikatan dalam aqad al-qardh harus ada barang sebagai perikatan atau transaksi (objek akad). Syarat objek akad adalah dapat menerima hukumnya.

3. Maudhu' al 'aqd adalah tujuan atau maksud pokok mengadakan akad. Berbeda kad, maka berbeda tujuan pokok akad, dalam akad jual beli yujuan pokoknya ialah meminfahkan barang dari penjual kepada pembeli dengan diberi ganti, dan dalam akad jual beli ini akan mendapatkan keuntungan, berbeda dengan perikatan atau aqar al-qardh, dalam aqad al-qardh tujuan pokok perikatannya adalah tolong menolong dalam arti meminjamkan harta tanpa mengharapkan imbalan, uang yang di pinjamkan di kembalikan sesuai dengan uang yang dipinjamkan, tidak ada tambahan dalam pengembalian uangnya. Saratnya adalah ada itikad baik.10

4. Shighat al-'aqd ialah ijab dan qabul, ijab adalah permulaan 
180 | Diktum: Jurnal Syari'ah dan Hukum, Volume 16, Nomor 2 Desember 2018 : 171 - 186

penjelasan yang keluar dari salah seorang yang berakad sebagai gambaran kehendaknya dalam mengadakan akad, sedangkan qabul adalah perkataan yang keluar dari pihak berakad pula, yang diucapkan setelah adanya ijab. Pengertian ijab qabul dalam pengamalan dewasa ini ialah bertukarnya sesuatu dengan yang lain sehingga penjual dan pembeli dalam membeli sesuatu terkadang tidak berhadapan, seperti dalam akad salam ${ }^{11}$ Syaratnya adalah ijab itu berjalan terus, tidak dicabut sebelum terjadinya kabul. Maka bila orang yanh berijab menarin kembali ijabnya sebelum kabul, maka batalah ijabnya. Ijab dan qabul mesti bersambung sehingga bila seseorang yang berijab sudah berpisah sebelum adanya kabul, maka ijab tersebut menjadi batal. ${ }^{12}$

Dalam praktik perbankan Syariah, rukun dan syarat dalam aqad al-qardh selain diatas adalah: a. Bank (pihak yang menyediakan uang atau meminjamkan harta);

b. Nasabah (pihak yang meminjam uang);

c. Proyeksi usaha (tujuan dalam mengadakan perikatan al-qardh) ${ }^{13}$

Sifat qardh ini tidak memberikan keuntungan finansial. Karena itu, pendanaan qardh dapat diambil menurut kategori berikut:

a. Al-qardh yang diperlukan untuk membantu usaha sangat kecil dan keperluan sosial, dapat bersumber dari dana zakat, infaq, dan sedekah.

b. Al-qardh yang diperlukan untuk membantu keuangan nasabah secara cepat dan berjangka pendek. Talangan dana di atas dapat diambilakan dari modal bank.

D. Praktik Aqad Al-Qardh dalam Perbankan Syariah

Akad al-Qardh biasanya diterapkan sebagai berikut:

1. Sebagai produk pelengkap kepada nasabah yang telah 
terbukti loyalitas dan Pinjaman qardh biasanya bonafiditasnya, yang diberikan oleh bank kepada membutuhkan dana talang nasabahnya sebagai fasilitas pinjaman segera untuk masa yang relatif talangan pada saat nasabah mengalami pendek. Nasabah tersebut akan overdraft. Fasilitas ini dapat mengembalikannya secepatnya merupakan bagian dari satu paket sejumlah uang yang dipinjamnya pembiayaan lain, untuk memudahkan itu.

nasabah bertransaksi. Aplikasi qardh

2. Sebagai fasilitas nasabah yang dalam perbankan ada empat hal:

memerlukan dana cepat, a. Sebagai pinjaman talangan haji sedangkan ia tidak bisa menarik dananya karena, misalnya, b. Sebagai pinjaman tunai dari tersimpan dalam bentuk deposito. produk kartu kredit syariah c. Sebagai pinjaman kepada pengusaha kecil

3. Sebagai produk untuk menyumbangkan usaha yang sangat kecil atau membantu sektor sosial. Guna pemenuhan skema khusus ini telah dikenal suatu produk khusus yaitu alqardh al-hasanah. ${ }^{14}$

4. Sebagai dana talang untuk janga waktu singkat, maka nasabah akan mengembelikannya dengan cepat, seperti kompensating balance dan factoring (anjak piutang). ${ }^{15}$

d. Sebagai pinjaman kepada pengurus bank

Sifat al-Qardh tidak memberikan keuntungan finansial. Karena itu, pendanaan qardh dapat diambil menurut kategori berikut:

a. Al-qardh yang diperlukan untuk keuangan nasabah secara cepat dan berjangka pendek.talangan dana diatas dapat diambilkan dari modal bank.

b. Al-qardh yang diperlukan untuk membantu usaha sangat kecil dan keperluan sosial, dapat bersumbe 
182 | Diktum: Jurnal Syari'ah dan Hukum, Volume 16, Nomor 2 Desember 2018 : 171 - 186

dari dana zakat, dan sedekah.

Disamping sumber dana umat, para praktisi perbankan syariah, demikian juga ulama, melihat adanya sumber dana lain yang dapat dialokasikanuntuk qardh alhasan, yaitu prndapat-pendapat yang diragukan, seperti jasa nostro di bank korespondensi yang konvensional, bunga atas jaminan L/C di bank asing, dan sebagainya. Salah satu pertimbangan pemanfaatan danadana ini adalah kaidah akhaffu dhararain (mengambil mudharat yang lebih keci). Hal ini mengingat jika dana umat Islam dibiarkan di lembaga-lembaga non-muslim mungkin dapat dipergunakan untuk sesuatu yang merugikan Islam, misalnya dana kaum muslimin Arab di bank-bank Yahudi Switzerland. Oleh karena itu, dana yang parkir tersebut lebih baik diambil dan dimanfaatkan untuk penanggulangan bencana alam atau membantu dhu'afa.
Manfaat aqad al-qardh banyak sekali, diantaranya:

a. Memungkikan nasabah yang sedang dalam kesulitan mendesak untuk mendapatkan dana talangan jagka pendek.

b. Al-qardh al-hasan juga merupakan salah satu ciri pemberi antara bank syariah dan bank konvensionalyang didalamnya terkandung misi sosial, disamping misi komersial.

c. Adanya misi-sosial kemasyarakatkatan ini akan meningkatkan citra baik dan meningkatkan loyalitas masyarakat terhadap bank syariah.

d. Risiko al-qardh terhitung tinggi karena ia di anggap pembiayaan yang tidak ditutup dengan jaminan. ${ }^{16}$

Akad qard biasanya diterapkan sebagai berikut :

a. Sebagai produk pelengkap kepada nasabah yang telah terbukti loyalitas dan bonafiditasnya, yang membutuhkan dana talangan segera untuk masa yang relative pendek. Nasabah tersebut akan 
mengembalikan secepatnya sejumlah uang yang dipinjam itu.

b. Sebagai fasilitas nasabah yang memelurkan dana cepat, sedangkan ia tidak bisa menarik dananya karena, misalnya, tersimpan dalam bentuk deposito

c. Sebagai produk untuk menyumbang usaha yang sangat kecil atau membantu sector sosial guna pemenuhan skema khusus ini telah dikenal suatu produk khusus yaitu Al-Qardh Al-Hasan.

Sifat al Qardh tidak memberi keuntungan financial. Karena itu pendanaan qardh dapat diambil menurut kategori berikut.

a. Al Qardh yang diperlukan untuk membantu keuangan nasabah secara cepat dan berjangka pendek. Talangan dana diatas dapat diambilkan dari modal bank.

b. Al Qardh yang diperlukan untuk membantu usaha sangat kecil dan keperluan sosial, dapat bersumber dari dana zakat, infak, dan sedekah. Disamping sumber dana umat, para praktisi perbankan syariah, demikian juga ulama, melihat adanya sumber dana lain yang dialokasikan untuk Al Qardh Al Hasan, yaitu pendapatanpendapatan yang diragukan, seperti jasa nostro di bank koresponden yang konvensional, bunga atas jaminan $\mathrm{L} / \mathrm{C}$ di bank asing, dan sebagainya. Salah satu pertimbangan pemanfaatan danadana ini adalah kaidah Akhaffu Dhararain (mengambil mudharat yang lebih kecil). Hal ini mengingat jika dana umat Islam dibiarkan di lembaga-lembaga non muslim mungkin dapat dipergunakan untuk sesuatu yang merugikan Islam, misalnya dana kaum muslimin Arab di bank-bank Yahudi Switzerland. Oleh karenanya, dana yang parker tersebut lebih baik diambil dan dimanfaatkan untuk penanggulangan bencana alam atau membantu dhua'afa.

Manfaat akad Al Qardh banyak sekali, diantaranya : 
184 | Diktum: Jurnal Syari'ah dan Hukum, Volume 16, Nomor 2 Desember 2018 : 171 - 186

a. Memungkinkan nasabah yang lain, aqad al-Qardh merupakan sedang dalam kesulitan mendesak pinjaman oleh pihak bank kepada untuk mendapat talangan jangka nasabah tanpa adanya imbalan, pendek.

b. Al Qardh Al Hasan juga perikatan jenis ini bertujuan untuk merupakan salah satu ciri pembeda antara bank syariah dan bank konvensional yang di dalamnya terkandung misi social, disamping misi komersial.

c. Adanya misi social kemasyarakatan ini akan meningkatkan loyalitas masyarakat terhadap bank syariah.

\section{PENUTUP}

Akad Al-Qardh adalah perikatan atau perjanjian antara kedua belah pihak, dimana pihak pertama menyediakan harta atau memberikan harta dalam arti meminjamkan kepada pihak kedua sebagai peminjam uang atau orang yang menerima harta yang dapat ditagih atau diminta kembali harta tersebut, dengan kata lain meminjamkan harta kepada orang lain yang mebutuhkan dana cepat tanpa mengharapkan imbalan. Dengan kata

menolong, bukan sebagai perikatan yang mencari unt ung (komersil).

Dalil yang melandasi diperbolehkannya aqak al-Qardh ini tercantum dalam al-Quran surat. AlHadid : Di jelaskan yang menjadi landasan dalil dalam ayat ini adalah kita diseru untuk "meminjamkan kepada Allah", artinya untuk membelanjakan harta dijalan Allah. Selaras dengan meminjamkan kepada Allah, kita juga diseru untuk 'meminjamkan kepada sesama manusia", sebagai bagian dari kehidupan bermasyarakat (civil society). Rukun dan syarat dalaam aqad al-Qardh yang lebih sempitnya adalah subjek perikatan (al-'aqidain), objek perikatan (mahallul 'aqad), tujuan perikatan (maudhu'ul 'aqad), dan aigat 'aqad (ijab dan kabul).

Unsur-unsur dalam aqad alQardh adalah pertalian ijab dan kabul, dibenarkan oleh Syara', dan 
mempunyai akibat hukum. Selain itu dalam praktk perbankan harus ada bank, nasabah, dan proyeksi usaha. Praktik dalam perbankannya diantaranya sebagai dana talang untuk jangka waktu singkat, maka nasabah akan mengembalikannya dengan cepat, sebagai fasilitas untuk memperoleh dana cepat karena nasaba tidak bisa menarik dananya, misalnya karena tersimpat dalam deposito, sebagai fasilitas membantu usaha kecil atau sosial.

Manfaat aqad al-qardh adalah membantu nasabh yang membutuhkan dana cepat, alqardh al-hasan juga merupakan salah satu ciri pemberi antara bank syariah dan bank konvensionalyang didalamnya terkandung misi sosial, disamping misi komersial, meningkatkan citra baik dan meningkatkan loyalitas masyarakat terhadap bank syariah. 
186 | Diktum: Jurnal Syari'ah dan Hukum, Volume 16, Nomor 2 Desember 2018 : 171 - 186

\section{DAFTAR PUSTAKA}

Antonio, Muhammad Syafi'i. 2001. Bank Syariah dari Teori ke Praktik. Depok: Gema Insani..

Anwar, Syamsul. 2010. Hukum Perjanjian Syariah. Jakarta: Rajawali Pers..

Dewi, Gemala. 2007. Hukum Perikatan Islam di Indonesia. Jakarta: Kencana Pernada Media Group.

Fatwa DSN (Dewan Syariah Nasional) NO: 19/DSN-MUI/IV/2001

Ghazaly, Abdul Rahman. 2010. Fiqh Muamalah. Jakarta: Kencana Pernada Media Group.

Kementerian Agama RI, Al Qur'an dan Terjemahnya. Bandung: PT. Madinah Raihan Makmur, 2010.

Rusdi, Muhammad Ali. (الفقر و علاجه في ) تصور القرآن (دراسة لغوية تفسيرية ) Langkawi: Journal of The Association for Arabic and English, 2015, 1.1: 85-103.

Suhendi, Hendi. 2010. Fiqh Muamalah. Jakarta: PT RajaGrafindo Persada.

\section{Catatan Akhir}

${ }^{1}$ Ahmad Abu al-Fath, Al-Mu'amalat fil asy-Syari'ah al-Islamiyyah wa al-Qawanin al-Mishriyyah. Lihat RUSDI, Muhammad Ali. الفقر وعلاجه فى تصور القرآن (دراسة لغوية تفسيرية) Langkawi: Journal of The Association for Arabic and English, 2015, 1.1: 85-103.

${ }^{2}$ H. Hendi Suhendi, Fiqh Muamalah (Jakarta:PT. Raja Grafindo Persada, 2010) h. 45.

3 Basya, "Mursyid al-Hairan ila Ma'rifah Ahwal al-Insan”, h. 49.

${ }^{4}$ Syamsul Anwar, Hukum Perjanjian Syariah (Jakarta:Kencana Pernada Media Group), h. 69.

${ }^{5}$ Hendi Suhendi, Fiqh Muamalah, h. 46.

${ }^{6}$ Muhammad Syafi'i Antonio, Bank Syariah dari Teori ke Praktik (Depok: Gema Insani), h.131.

7 Gemala Dewi, Hukum Perikatan Islam di Indonesia (Jakarta: Kencana Pernada Media Group), h. 48.

${ }^{8}$ Muhammad Syafi'i Antonio, Bank Syariah dari Teori ke Praktik. h. 132.

${ }^{9}$ Abdul Rahman Ghazaly, Fiqh Muamalat, (Jakarta: Kencana Pernada Media Grroup), h. 52.

${ }^{10}$ Hendi Suhendi, Fiqh Muamalah, h. 47.

${ }^{11}$ Abdul Rahman Ghazaly, Fiqh Muamalat, h. 52.

${ }^{12}$ Hendi Suhendi, Fiqh Muamalah, h. 50.

${ }^{13}$ Muhammad Syafi'i Antonio, Bank Syariahdsri Teori ke Praktik. h.134.

${ }^{14}$ Muhammad Syafi'i Antonio, Bank Syariah dari Teori ke Praktik. h. 133.

${ }^{15}$ Gemala Dewi, Hukum Perikatan Islam di Indonesia, h.159.

${ }^{16}$ Muhammad Syafi'i Antoni, Bank Syariah dari Teori ke Praktik, h. 134. 